\title{
Wpływ alternatywnych sposobów rozwiązywania sporów na efektywność ochrony prawnej
}

\section{Uwagi wprowadzające}

Z

asada efektywności (effectiveness, effet utile), chociaż nie została wyraźnie wyartykułowana w traktatach, pełni istotną funkcję w systemie unijnej ochrony prawnej, w szczególności zaś uzasadnia ograniczenie zasady autonomii proceduralnej państw członkowskich, stanowi podstawę prawną dla ustanowienia roszczeń obywateli Unii Europejskiej niemających oparcia w wyraźnym przepisie prawa wspólnotowego, uzasadnia określanie przez Europejski Trybunał Sprawiedliwości obowiązków sądów państw członkowskich w zakresie wykładni i stosowania prawa wspólnotowego, stanowi dyrektywę interpretacyjną dla sądów państw członkowskich w tym zakresie ${ }^{1}$.

Oczywiście problem efektywności prawa może być rozpatrywany już na etapie jego stanowienia, ale przedmiotem niniejszego opracowania będą zagadnienia związane z efektywnością rozumianą jako ostateczne osiągnięcie założonego rezultatu przez normy unijne, a więc spowodowanie, że normy te będą wywoływały pełnię założonych skutków w praktyce. Oznacza to skupienie się na elementach związanych z efektywną ochroną praw podmiotowych.

\footnotetext{
* Dr hab. Prof. Nadzw. Renata Świrgoń-Skok - Zakład Prawa Cywilnego i Prawa Rzymskiego Wydział Prawa i Administracji Uniwersytet Rzeszowski ul.Grunwaldzka13, 35-068 Rzeszów.

** Dr Aneta Arkuszewska - Zakład Prawa Cywilnego Wydział Prawa i Administracji Uniwersytet Rzeszowski ul.Grunwaldzka13, 35-068 Rzeszów.

${ }^{1}$ Szerzej zob. S. Biernat, Zasada efektywności prawa wspólnotowego w orzecznictwie Europejskiego Trybunału Sprawiedliwości, Studia z prawa Unii Europejskiej w piąta rocznicę utworzenia Katedry Prawa Europejskiego Uniwersytetu Jagiellońskiego, red. S. Biernata, Kraków 2000, s. 27; N. Półtorak, Odpowiedzialność odszkodowawcza państwa w prawie Wspólnot Europejskich, Kraków 2002, s. 66 i n.
} 
Sprawy z zakresu prawa prywatnego (sprawy cywilne) mogą być realizowane nie tylko przez państwowe organy sądowe, lecz także przez powołane do tego wolą stron sądy polubowne (arbitrażowe). Jest to możliwe dzięki fundamentalnej dla prawa prywatnego zasadzie autonomii woli, która na gruncie postępowania cywilnego wyraża się m.in. poprzez umożliwienie stronom dokonania wyboru, czy zwrócą się o udzielenie ochrony do sądu państwowego, czy skorzystają z innej drogi dochodzenia roszczenia. ${ }^{2}$ Istota arbitrażu sprowadza się do funkcjonowania sądów polubownych, złożonych z jednego lub większej liczby sędziów (arbitrów), którym zostaje powierzone, w miejsce sądów państwowych i na podstawie woli stron, rozpoznawanie i rozstrzyganie sporów cywilnoprawnych ${ }^{3}$. Sąd arbitrażowy powinien pełnić nie tylko funkcję organu rozstrzygającego spory w trybie orzeczniczym, ale co istotniejsze powinien rozwiązywać te spory przy udziale stron tak, aby możliwe było ich pojednanie lub co najmniej zapobieganie dalszej antagonizacji ${ }^{4}$. Przy określaniu jego istoty akcentuje się również to, że obejmuje ono pozasądowe procedury rozwiązywania sporów, prowadzone z udziałem neutralnego podmiotu trzeciego, które mają stanowić alternatywę względem rozwiązywania sporu w drodze jego rozstrzygnięcia przez sąd powszechny $y^{5}$. Taką właśnie alternatywę stanowi poddanie sporu pod rozstrzygnięcie bezstronnego arbitra, a więc osoby niebędącej sędzią państwowym.

Stąd też tak istotne jest zadbanie o sprawność i efektywność postępowań toczących się przed sądem polubownym, i spojrzenie na te kwestie w szerszym aspekcie postępowania cywilnego. Wynika to przede wszystkim $\mathrm{z}$ faktu, że chociaż sądownictwo polubowne nie jest częścią składową sądownictwa państwowego, to jednak działając zamiast sądów państwowych i udzielając ochrony prawnej, jako takie realizują zadania, które należą do państwa, zatem państwo sankcjonuje działalność sądów polubownych ${ }^{6}$. Tym samym wiele problemów odnoszących się do przebiegu postępowania przed sądem państwowym można

2 Zob. Ł. Błaszczak, M. Ludwik, Sąownictwo polubowne (arbitraż), Warszawa 2007, s. 23; T. Strumiłło, Zasady postępowania arbitrażowego, “Kwartalnik ADR” 2009, nr 3, s. 62.

${ }_{3}^{3}$ Zob. W. Broniewicz, Postępowanie cywilne w zarysie, Warszawa 2008, s. 401; S. Dalka, Sądownictwo polubowne w PRL, Warszawa 1987, s. 17; T. Ereciński, K. Weitz, Sąd arbitrażowy, Warszawa 2008, s. 16; A. Wach, Alternatywne formy rozwiązywania sporów sportowych, Warszawa 2005, s. 134; A. Mól, Pojęcie i znaczenie alternatywnych metod rozstrzygania sporów (ADR), "Przegląd Prawa Handlowego" 2001, nr 12, s. 29; J. Rajski, Regulamin ADR Międzynarodowej Izby Handlowej z 2001 roku, "Przegląd Prawa Handlowego" 2001, nr 11, s. 38-39; Z.Kierczyński, Czy przedsiębiorcy powinni korzystać z sądownictwa polubownego?, Mediacja i arbitraż jako sposoby polubownego rozstrzygania sporów, red. D. Czura-Kalinowska, Poznań 2009, s. 175.

${ }^{4}$ J. Rajski, Nowe wyzwania wobec sądów arbitrażowych, "Przegląd Prawa Handlowego" 2001, nr 1, s. 2.

${ }^{5}$ Zob. P. Sobolewski, Mediacja w sprawach cywilnych, "Przegląd Prawa handlowego" 2006, nr 2, s. 32; A. Wach, Alternatywne formy rozwiązywania sporów sportowych, Warszawa 2005, s. 124-125.

${ }^{6} \mathrm{~K}$. Weitz, Sądownictwo polubowne a sądownictwo państwowe, "Przegląd Sądowy" 2007, Nr 3, s. 6-7 i przytoczona przez autora literatura. 
odnaleźć również w toku postępowania arbitrażowego, choć dzięki swojej elastyczności to ostatnie z pewnością dysponuje większym zakresem środków, pozwalających na uniknięcie niesprawności i nieefektywności prowadzonych czynności.

Celem artykułu jest ukazanie wpływu alternatywnych sposobów rozwiązywania sporów na efektywność ochrony prawnej na przestrzeni wieków, począwszy od prawa rzymskiego po współczesne polskie rozwiązania prawne. Ponieważ rzymska myśl prawna twórczo zaadaptowana do potrzeb kolejnych pokoleń, znajduje swoje zastosowania również wobec wyzwań współczesnego procesu cywilnego. W tym także w odniesieniu do kwestii związanych z potrzebą zapewnienia realizacji prawa dostępu do sądu i prawa do efektywnego procesu cywilnego.

\section{Pojęcie efektywności ochrony prawnej}

W aktach normatywnych Unii Europejskiej brakuje definicji pojęcia efektywnej ochrony prawnej, także Europejski Trybunał Sprawiedliwości jej nie definiuje. Stwierdza jedynie, że jest ona jedną z generalnych zasad unijnego porządku prawnego wywodzoną z tradycji konstytucyjnej wspólnej państwom członkowskim i potwierdzoną w Europejskiej Konwencji o Ochronie Praw Człowieka i Podstawowych Wolności ${ }^{7}$. Na podstawie wskazówek wynikających z dotychczasowego orzecznictwa ETS można uznać, że efektywna ochrona prawna oznacza obowiązek zapewnienia ochrony i wykonania wszelkich uprawnień jednostek wynikających z prawa unijnego ${ }^{8}$.

Zasada ta powinna być realizowana przez organy państw członkowskich, jak i przez organy Unii. Wszystkie organy Unii Europejskiej i organy krajowe wykonujące prawo wspólnotowe powinny, w odniesieniu do jednostek, kierować się zasadą efektywnej ochrony prawnej. Szczególna rola przypada tu ETS i sądom krajowym. Kontrola sprawowana przez ETS nad działalnością organów unijnych zapewnia wykonanie praw jednostek przez te organy (np. skarga na akt prawny wydany przez organy Unii, skargę na bezczynność organu, powództwo o odszkodowanie). ETS kontroluje także wykonywanie przez państwa członkowskie ich zobowiązań wobec Unii Europejskiej, w tym wykonanie uprawnień jednostek wynikających z prawa unijnego. Jednak nad wykonaniem uprawnień jednostek przez organy państw członkowskich czuwają przede wszystkim sądy krajowe, do których jednostka może się zwrócić bezpośrednio z odpowiednią skargą ${ }^{9}$.

7 Zob. np. orzeczenie 222/84 Marguerite Johnston v. Chief Constable of the Royal Ulster Constabulary [1986] ECR 1651, pkt 14.

${ }^{8}$ Zob. szerzej N. Półtorak, Odpowiedzialność..., s. 106 i n.

9 Potwierdza to m. in. orzeczenie ETS w sprawie Union de Pequ- eńos Agricultores4 („UPA”). 
Ponadto jest to zasada, której treść jest stale konkretyzowana, uzupełniana i dopełniana w orzecznictwie ETS- $u$, a jej zakres ulega stałemu poszerzaniu o nowe instytucje i zagadnienia nie tylko procesowe. Mieszczą się w niej zatem, także alternatywne sposoby rozwiązywania sporów.

Również na gruncie prawa polskiego brakuje legalnej definicji zasady efektywności ochrony prawnej. Przez to pojęcie rozumie sie najczęściej sprawność, wydajność, oraz skuteczność dającą pozytywne wyniki ${ }^{10}$. Mówiąc o sprawności, odnosimy się do toku procesu cywilnego, stanu jego zorganizowania (w tym szybkości), który ma prowadzić do osiągnięcia zamierzonego celu, natomiast termin efektywność postępowania odnosi się również do jego skutku, do stopnia osiągnięcia założonego celu ${ }^{11}$. Cel postępowania cywilnego jest jasno określony i jest nim wydanie trafnego orzeczenia dla zapewnienia należytej ochrony prawnej. podmiotowi, który tej ochrony poszukuje lub uzyskanie ugody między stronami.

W literaturze przedmiotu można odnaleźć próby zdefiniowania pojęcia efektywność postępowania cywilnego. I tak np. za efektywny proces cywilny, uznaje sie taki, który umożliwia w optymalnym zakresie rzeczywistą ochronę prawną. Ocenia on efektywność tego procesu przy pomocy stopnia osiągniętego rezultatu w stosunku do zamierzonego celu ${ }^{12}$. Poza tym efektywność ochrony prawnej udzielanej przez sądy może być analizowana z punktu widzenia konstytucyjnej i ustrojowej roli sądów cywilnych, pozycji sędziego, adekwatności procedur sądowych czy też formalnych gwarancji rzetelnego procesu cywilnego. Skuteczność tej ochrony można także badać z punktu widzenia rzeczywistych barier dostępu do sądów, istnienia i znaczenia alternatywnych sposobów rozstrzygania sporów cywilnych czy wreszcie przez pryzmat faktycznego postrzegania roli sądów w opinii społecznej ${ }^{13}$ (np. taka organizacja postępowania sądowego w sprawach cywilnych, aby z jednej strony możliwie jak najszybciej zapewnić udzielenie ochrony prawnej zainteresowanym podmiotom, a z drugiej strony, aby ochrona taka mogła być oceniona jako skuteczna). Efektywność ochrony prawnej oznaczać może także uprawnienie do formułowania roszczeń o rzeczywiście skuteczną sędziowską kontrolę określonego fragmentu życia społecznego i zachodzących pomiędzy jego uczestnikami interakcji ${ }^{14}$. Wymóg takiej ochrony będzie najlepiej spełniony, gdy naruszenie prawa będzie usunięte na

${ }^{10}$ Nowy słownik języka polskiego, red. E. Sobol, Warszawa 2003, s.179.

${ }^{11}$ K. Flaga - Gieruszyńska, Problem sprawności i efektywności postępowania arbitrażowego, "Kwartalnik ADR", 2011, nr 4(16), s. 165.

${ }^{12}$ L. Nevai, Efektywność a demokratyzm socjalistycznego procesu cywilnego, "Państwo i Prawo" 1973, nr 7, s. 36. Podobnie M. Sawczuk, O efektywności socjalistycznego postępowania cywilnego, "Studia Cywilistyczne" 1975, t. XXV-XXVI, s. 257 i n.

${ }_{13}$ T. Ereciński, K. Weitz, Efektywność ochrony prawnej udzielanej przez sądy w Polsce, "Przegląd Sądowy" 2005, nr 10, s. 3.

${ }^{14}$ B. Wojciechowski, Rozpoznanie sprawy w rozsądnym terminie. Uwagi na tle tworzenia europejskiego kodeksu postępowania cywilnego i orzecznictwa Europejskiego Trybunału Praw Człowieka, 
mocy kształtującego orzeczenia sądowego ze skutkiem ex tunc bądź też zostanie ukonstytuowany obowiązek do jego usunięcia w drodze pozytywnej działalności wyrokującego sędziego (np. w rozsądnym terminie). Ponadto akcentowany jest jeszcze aspekt ekonomiczny efektywnej ochrony prawnej, tj. uwzględnienie czasu realizacji oferowanych usług, ich kosztów, ze wskazaniem użytych zasobów oraz jakości świadczonych usług, mierzonej wskaźnikiem spraw, w których wyrok został podtrzymany w wyższej instancji albo nie złożono od niego odwołania ${ }^{15}$.

Również w odniesieniu do sądownictwa polubownego badacze tematu ${ }^{16}$ podają warunki jakie powinny zostać spełnione, aby postępowanie realizowało efektywną ochronę sadową. Zaliczają do nich $\mathrm{m}$. in. uczciwy proces; prawidłowość merytorycznego rozstrzygnięcia sporu; właściwe ukształtowanie trybu postępowania; czas postępowania arbitrażowego; rozsądną wysokość i sprawiedliwy podział kosztów arbitrażu; poufność postępowania; wykonalność uzyskanego tytułu egzekucyjnego, formy i treści zapisu na sąd polubowny, możliwości uzyskania tymczasowych zabezpieczeń przed rozpoczęciem i w czasie trwania postępowania przed sądem polubownym, powoływania i wyłączania arbitrów, pomocy sądów państwowych, wykluczenia odwołania (apelacji) od wyroku sądu polubownego, podstaw uchylania takiego wyroku (zwłaszcza niedopuszczalność jego merytorycznej kontroli).

\section{Sądownictwo polubowne w prawie rzymskim, a efektywna ochrona praw podmiotowych}

Prawo rzymskie znało postępowanie polubowne, gdy strony na podstawie porozumienia powierzały rozstrzygnięcie sporu osobie prywatnej, której decyzji poddały się z góry. Takie postępowanie było znane także innym prawom antycznym, ale dopiero jego opracowanie przez Rzymian wpłynęło na dalszy rozwój tej instytucji. Jego główną podstawą była regulacja rzymska, mająca jednak pewne słabe punkty, które od średniowiecza były poprawiane i uzupełniane.

W prawie rzymskim strony, które nie chciały udziału czynnika państwowego w rozwiązaniu istniejącego pomiędzy nimi konfliktu, mogły zgodzić się na poddanie swego sporu pod rozstrzygnięcie osoby trzeciej. Toczyło się wówczas nieformalne postępowanie przed ustanowionym przez strony sędzią polubownym

\footnotetext{
Teoretycznoprawne problemy integracji europejskiej, red. L. Leszczyński, Lublin 2004, s. 190-191 i przywołana przez autora literatura.

${ }^{15}$ J. Bełdowski, S. Sześciło, Stan wymiaru sprawiedliwości w Polsce wświetle międzynarodowych badań porównawczych, http://www.monitorprawniczy.pl/index.php?mod=m_artykuly\&cid=53\&id=2613, (dostęp 19.12.2017); B. Stelmach, B. Brożek, Dziesięć wykładów o ekonomii prawa, Kraków 2007, s. 25-50.

${ }^{16}$ K. Flaga - Gieruszyńska, Problem sprawności, s. 164 i n
} 
(arbiter). Takie postępowanie występowało już w okresie przedklasycznym ${ }^{17}$, natomiast w okresie klasycznym zapis na sąd polubowny dokonywały strony poprzez zawarcie nieformalnego porozumienia, które było podstawą działania dla arbitra (compromissum)18. Niekiedy obok nieformalnej umowy o zapis na sąd polubowny zawierane było dodatkowe nieformalne porozumienie zwane receptum arbitri, na podstawie którego osoba wskazana przez strony jako arbiter dobrowolnie przyjmowała na siebie taką funkcję i zobowiązywała się do rozstrzygnięcia sporu pod rygorem zapłaty grzywny (multae dictio) lub wzięcia określonych przedmiotów w zastaw przez magistraturę w celu wykonania rozkazu (pignoris capio). Nie było tutaj natomiast sankcji w postaci skargi sądowej, a tylko wyżej wskazane pretorskie środki przymusu ${ }^{19}$. Zaś w okresie poklasycznym każde compromissum zawierane było w drodze nieformalnego porozumienia (pactum), a kara umowna uzależniona w prawie klasycznym od złożonych wcześniej stypulacji, stała się elementem charakterystycznym dla kompromisu $^{20}$. Z kolei w prawie justyniańskim compromissum mogło zostać zawarte $\mathrm{w}$ dwóch formach, albo $\mathrm{w}$ formie pisemnej, lub przez złożenie ustnego oświadczenia do protokołu sądu polubownego. Wymagane było jednocześnie złożenie przysięgi przez strony i arbitra ${ }^{21}$, przynajmniej do roku 539 kiedy to zamiast przysięgi Justynian wprowadził, aby skutki odmowy zastosowania się do orzeczenia arbitra poddać wyrokowi sędziego ${ }^{22}$.

Współczesnych elementów efektywnej ochrony sądowej można doszukiwać się w rzymskim postępowaniu polubownym prowadzonym na podstawie compromissum. Przypominało ono bowiem, postępowanie sądowe i służyło do zakończenia istniejących sporów ${ }^{23}$.

Podstawowym obowiązkiem arbitra było merytoryczne rozstrzygnięcie sporu. Kwestią sporna było wywiązanie się przez arbitra z obowiązku rozstrzygnięcia sprawy. Dlatego też arbiter składał zobowiązanie, że nie uchyli się od orzekania i narażał się na kary pieniężne, gdyby nie wydał orzeczenia (D.4,8; C.2,55). Jeżeli

17 Zob. Verg., Ecl. 3,28-37; Cic.,in Verr.2,2,27,66; D.4,8,11,2 Ulpian; D.16,3,6 Paulus; Plutarch, Merc. 736 - 738; Plutarch, Rud. 1001-1002; 1017-1018; D.4,8,11,2 Paulus. Szerzej na temat polubownego rozwiązywania sporów pisze M. Żołnierczuk, Rzymskie sądownictwo polubowne (okres przedklasyczny i klasyczny), Lublin 1978, s. 58 i n; oraz Festus, de verb. Sign., s.v. sequester,H. Heumann, E. Seckel, Handlexicion zu den Quellen des römischen Rechts, Graz 1958, s. 535; J. Sondel, Szczególne rodzaje depozytu w prawie rzymskim, Kraków 1967, s. 100 i n.

${ }_{18}$ D.4,8,32,21 (Paulus): Arbiter nihil extra compromissum facere potest.

19 D.4,8,2 (Ulpianus): Ex compromisso placet exceptionem non nasci, sed poenae petitionem.

${ }^{20}$ Od 395 roku dochodzenie kary umownej wynikało bezpośrednio z zwartego porozumienia - CTh. 15,14,9.

${ }^{21}$ Zob. C.2, $55,4 \mathrm{pr}-1$

${ }^{22}$ Por. Nov.82,11,1

${ }^{23}$ D.4,8,1 (Paulus): Compromissum ad similitudinem iudiciorum redigitur et ad finiendas lites pertinet. 
wyrok przez sędziego polubownego został wydany przed zawarciem wyżej wspomnianej umowy strony mogły poddać się decyzji arbitra albo w drodze uznania takiego rozstrzygnięcia $\mathrm{w}$ formie pisemnej lub milcząco, jeżeli w ciągu 10 dni nie dokonały opozycji (attestatio).

Ponadto nad prawidłowym przebiegiem postępowania polubownego czuwał pretor, który nie miał wprawdzie uprawnień, aby zmusić kogoś do przyjęcia funkcji sędziego polubownego, natomiast w przypadku powołania podlegał jego kontroli i mógł zostać przymuszony do wykonania obowiązków. Wynikało to z pretorskiej troski o bezstronność arbitra i rzetelny przebieg postępowania polubownego (nie dotyczyło to jednak urzędników o wyższej lub równiej randze pretorowi) ${ }^{24}$. Sędzia polubowny, który wydał rozstrzygnięcie nie mógł go zmienić ${ }^{25}$. Ponadto rozstrzygając spór powinien odnosić się do warunków ustalonych w zapisie na sąd polubowny, nie mógł wykraczać poza ramy compromissum26.Tak samo mógł orzekać tylko odnośnie tych spraw, rozliczeń i sporów, które istniały miedzy stronami w momencie dokonania zapisu na sąd polubowny, a nie tych które powstały późnej ${ }^{27}$. Jednak istniały sytuacje, kiedy brak rozstrzygnięcia sprawy przez arbitra mógł zostać usprawiedliwiony, np. w przypadku jego zniesławienia, choroby, czy wieku ${ }^{28}$.

W źródłach prawa rzymskiego można także odnaleźć szczegółowe regulacje kto mógł pełnić funkcję sędziego polubownego (osoba wolno urodzona lub wyzwoleniec, nawet filius familias o ile ukończył 20 lat $^{29}$ ), jak również kto nie

${ }^{24}$ D.4,8,3,1 (Ulpianus): Tametsi neminem praetor cogat arbitrium recipere, quoniam haec res libera et soluta est et extra necessitatem iurisdictionis posita, attamen ubi semel quis in se receperit arbitrium, ad curam et sollicitudinem suam hanc rem pertinere praetor putat: non tantum quod studeret lites finiri, verum quoniam non deberent decipi, qui eum quasi virum bonum disceptatorem inter se elegerunt. finge enim post causam iam semel atque iterum tractatam, post nudata utriusque intima et secreta negotii aperta, arbitrum vel gratiae dantem vel sordibus corruptum vel alia qua ex causa nolle sententiam dicere: quisquamne potest negare aequissimum fore praetorem interponere se debuisse, ut officium quod in se recepit impleret?

${ }^{25}$ D.4,8,20 (Gaius): Quia arbiter, etsi erraverit in sententia dicenda, corrigere eam non potest.

${ }^{26}$ D.4,8,32,15 (Paulus): De officio arbitri tractantibus sciendum est omnem tractatum ex ipso compromisso sumendum: nec enim aliud illi licebit, quam quod ibi ut efficere possit cautum est: non ergo quod libet statuere arbiter poterit nec in qua re libet nisi de qua re compromissum est et quatenus compromissum est.

${ }_{27}$ D.4,8,46 (Paulus): De his rebus et rationibus et controversiis iudicare arbiter potest, quae ab initio fuissent inter eos qui compromiserunt, non quae postea supervenerunt.

${ }_{28}^{28}$ D.4,8,15 (Ulpianus): Licet autem praetor destricte edicat sententiam se arbitrum dicere coacturum, attamen interdum rationem eius habere debet et excusationem recipere causa cognita: ut puta si fuerit infamatus a litigatoribus, aut si inimicitiae capitales inter eum et litigatores aut alterum ex litigatoribus intercesserint, aut si aetas aut valetudo quae postea contigit id ei munus remittat, aut occupatio negotiorum propriorum vel profectio urguens aut munus aliquod rei publicae: et ita Labeo. oraz D.4,8,16 (Paulus).

${ }^{29}$ D.4,8,41 (Callistratus): Cum lege Iulia cautum sit, ne minor viginti annis iudicare cogatur, nemini licere minorem viginti annis compromissarium iudicem eligere: ideoque poena ex sententia 
mógł nim zostać (niewolnik, osoba niedojrzała, chora umysłowo, głucha lub niema $)^{30}$. Ponadto osoba, która pełniła funkcję sędziego w sporze cywilnym nie może zostać powołana na arbitra przez te same podmioty w tej samej sprawie ${ }^{31}$. Tak samo nie można było zostać sędzią polubownym we własnej sprawie ${ }^{32}$. Sędzia polubowny mógł być jeden, jak i kilku (wymagano wtedy liczby nieparzystej) ${ }^{33}$.

Do podstawowych obowiązków stron z compromissum należało wykonanie orzeczenia (definitio) arbitra, które strony gwarantowały albo wzajemną przysięgą albo stypulacyjnym (stipulatio poenae) przyrzeczeniem zapłaty kar umownych $^{34}$. Wykonanie orzeczenia arbitra mogło polegać albo na powstrzymaniu się od wytoczenia powództwa w tej samej sprawie w postępowaniu sądowym wbrew sentencji arbitra przez niezadowolonego powoda, albo na poddaniu się przez pozwanego sentencji arbitra nakazującej świadczenie, lub też wykonanie orzeczeń przygotowawczych przez powoda i pozwanego. W przypadku decyzji strony o niepoddaniu się orzeczeniu sądu polubownego konieczne było złożenie przez nią stosowanego oświadczenia i zapłata kary umownej (poena ex compromisso)35. Natomiast w przypadku uznania decyzji sądu polubownego zwycięski powód miał skargę (actio in factum), za pomocą której dochodził wykonania orzeczenia przed sądem państwowym, a zwycięski pozwany, w przypadku wszczęcia postępowania sadowego, mógł bronić się za pomocą specjalnego zarzutu procesowego (exceptio veluti pacti).

Postępowanie takie w państwie rzymskim, bez względu na okres czasu, cechowało się dużą swobodą oraz brakiem formalizmu, charakterystycznym zwłaszcza dla rzymskiego procesu zwyczajnego. Ponadto wśród zalet takiego postępowania wymienia się szybkość postępowania, dyskrecję oraz niskie koszty. To strony decydowały, kto będzie orzekać lub w jaki sposób zostaną wskazane właściwe po temu osoby. Kluczową kwestią pozostaje także zaufanie stron do arbitrów. Te wszystkie elementy mogą świadczyć, że w charakterze oraz

eius nullo modo committitur.

${ }^{30}$ D.4,8,9,1 (Ulpianus): Sed neque in pupillum neque in furiosum aut surdum aut mutum compromittetur, ut Pomponius libro trigensimo tertio scribit. Zob. także D.4,8,3,3 - D.4,8,8.

${ }^{31}$ D.4,8,9,2 (Ulpianus): Si quis iudex sit, arbitrium recipere eius rei, de qua iudex est, inve se compromitti iubere prohibetur lege Iulia: et si sententiam dixerit non est danda poenae persecutio.

${ }^{32}$ D.4,8,51 (Marcianus): Si de re sua quis arbiter factus sit, sententiam dicere non potest, quia se facere iubeat aut petere prohibeat...

${ }_{33}$ D.4,8,17,6 (Ulpianus): Principaliter tamen quaeramus, si in duos arbitros sit compromissum, an cogere eos praetor debeat sententiam dicere, quia res fere sine exitu futura est propter naturalem hominum ad dissentiendum facilitatem. in inpari enim numero idcirco compromissum admittitur, non quoniam consentire omnes facile est, sed quia et si dissentiant, invenitur pars maior, cuius arbitrio stabitur. sed usitatum est etiam in duos compromitti, et debet praetor cogere arbitros, si non consentiant, tertiam certam eligere personam, cuius auctoritati pareatur.

${ }^{34}$ Por. D.44,7,44,5 Paulus

${ }^{35} \mathrm{D} .4,8,38$ (Modestinus): Cum poena ex compromisso petitur, is qui commisit damnandus est, nec interest, an adversarii eius interfuit arbitri sententia stari nec ne. Por. także D.4,8,28-32. 
przebiegu postępowania polubownego w prawie rzymskim można odnaleźć te cechy, które współcześnie składają się na pojęcie efektywnej ochrony prawnej.

\section{Arbitraż w Polsce de lege lata, a efektywna ochrona praw podmiotowych}

Po przeprowadzonej w 2005 r. nowelizacji przepisów kodeksu postępowania cywilnego ${ }^{36}$ kompetencje sądu polubownego do prowadzenia i rozstrzygania sporów wynikają z woli stron wyrażanej w umowie, określanej - zgodnie $\mathrm{z}$ dotychczasową praktyką - mianem zapisu na sąd polubowny. W literaturze przyjmuje się, iż zapis na sąd polubowny stanowi centralną instytucję sądownictwa polubownego. ${ }^{37}$

Zgodnie z przepisami kodeksu postępowania cywilnego zapis na sąd polubowny może mieć postać wyłącznie umowy (art. 1161 k.p.c.). ${ }^{38}$ Zasadniczą formą zapisu na sąd polubowny pozostaje co prawda forma pisemna, jednak wymaganie dotyczące formy zapisu na sąd polubowny jest spełnione także wtedy, gdy zapis zamieszczony został $\mathrm{w}$ wymienionych między stronami pismach lub oświadczeniach złożonych za pomocą środków porozumiewania się na odległość, które pozwalają utrwalić ich treść (art. $1162 \$ 2$ zd.1 k.p.c.). Przy czym również powołanie się $\mathrm{w}$ umowie na dokument zawierający postanowienie o poddaniu sporu pod rozstrzygnięcie sądu polubownego spełnia wymagania dotyczące formy zapisu na sąd polubowny, jeżeli umowa ta jest sporządzona na piśmie,

${ }^{36}$ Ustawa z dnia 17.11.1964r., - Kodeks postępowania cywilnego (t.j. Dz. U. z 2016, poz. 1822 ze zm.).

${ }^{37}$ A. Budniak - Rogala, Charakter prawny zapisu na sad polubowny w postępowaniu cywilnym, Wrocław 2015, s. 73; R. Morek, Mediacja i arbitraż. Art. 1831 - 183 15, 1154 - 1217 KPC. Komentarz, Warszawa 2006 s. 127; Ł. Błaszczak, M. Ludwik, Sąownictwo polubowne..., s. 76.; J. J. Skoczylas, Charakter prawny zapisu na sąd polubowny a autonomia regulacji prawnej arbitrażu (po nowelizacji z 2005 roku), Księga pamiątkowa 60-lecia Sądu Arbitrażowego przy Krajowej Izbie Gospodarczej $w$ Warszawie, red. J. Okolski, A. Całus, M. Pazdan, S. Sołtysiński, E. Wardyński, S. Włodyka, Warszawa 2010, s. 136.

${ }^{38}$ Por. jednak - F. Zedler, Zapis na sad polubowny, Umowy w obrocie gospodarczym, red. A. Koch, J. Napierała, Warszawa 2006, s. 389; M. Tomaszewski, Umowa o arbitraż, System Prawa Handlowego. Arbitraż handlowy. red. S. Włodyka, A. Szumański, t. 8, Warszawa 2010, s. 267), którzy wskazują że gdy dochodzi do zawiązania spółki z ograniczoną odpowiedzialnością lub spółki akcyjnej przez jedną osobę (art. $151 \$ 1$ i $2 \mathrm{KSH}$ oraz art. $301 \$ 1 \mathrm{KSH}$ ) założyciel może wprowadzić do umowy spółki z ograniczoną odpowiedzialnością, czy też odpowiednio do statutu spółki akcyjnej, zapis na sąd polubowny obejmujący spory mogące wyniknąć ze stosunku spółki. Klauzula taka będzie wówczas wiązała zarówno spółkę, jak i jej wspólników (art. $1163 \$ 1$ KPC). W konsekwencji zapis na sąd polubowny może dojść do skutku w drodze jednostronnej de facto czynności prawnej założyciela spółki, a nie w drodze czynności prawnej dwustronnej czyli umowy (A. Budniak - Rogala, Charakter prawny zapisu..., s. 76) 
a to powołanie się jest tego rodzaju, że czyni zapis częścią składową umowy (art. $1162 \$ 2$ zd. 2 k.p.c.).

Liberalizacja formy zapisu na sąd polubowny związana jest $\mathrm{z}$ rozwojem techniki oraz wykorzystywaniem nowoczesnych środków przekazu elektronicznego. Umowa arbitrażowa może być zawarta za pomocą każdego środka porozumiewania się na odległość pod warunkiem jednakże, że pozwala on utrwalić jej treść. W związku z zawieraniem umów za pomocą środków komunikacji elektronicznej (na odległość) szczególnie istotne jest zapewnienie bezpieczeństwa obrotu z udziałem konsumentów. Art. $1164^{1} \$ 1$ k.p.c. ${ }^{39}$ nakazuje sporządzenie zapisu na sąd polubowny obejmujący spory wynikające z umów, których stroną jest konsument wyłącznie w formie pisemnej i tylko ex post (po powstaniu sporu). Nie jest możliwe w takiej sytuacji zawarcie umowy arbitrażowej za pomocą środków porozumiewania się na odległość ani w postaci klauzuli poprzez odesłanie. Ponadto w zapisie takim należy wskazać pod rygorem nieważności, że stronom znane są skutki zapisu na sąd polubowny, w szczególności co do mocy prawnej wyroku sądu polubownego lub ugody przed nim zawartej na równi $\mathrm{z}$ wyrokiem sądu lub ugodą zawartą przed sądem po ich uznaniu przez sąd lub po stwierdzeniu przez sąd ich wykonalności.

Postępowanie przed sądem polubownym jest mniej sformalizowane niż sądowe postępowanie cywilne w tym sensie, że podstawowe znaczenie dla przebiegu tego postępowania zachowuje autonomia woli stron, podczas gdy przepisy bezwzględnie obowiązujące stanowią niewielki fragment jego regulacji. Dzięki temu, pierwszeństwo w kształtowaniu zasad i sposobu postępowania przed sądem polubownym należy do stron, choć ich swoboda w tej sferze pozostaje oczywiście ograniczona wspomnianymi bezwzględnie obowiązującymi normami Części piątej kodeksu postępowania cywilnego, których strony nie mogą naruszyć przy określaniu norm procedury arbitrażowej. Ograniczenie to oznacza konieczność ukształtowania tej procedury w sposób, który w szczególności: zapewnia stronom równoprawne traktowani $\mathrm{e}^{40}$ oraz prawo do wysłuchania i przedstawienia swoich twierdzeń orz dowodów na ich poparcie (art. 1183 k.p.c.); wymaga odpowiednio wczesnego zawiadamiania stron o rozprawie oraz posiedzeniach sądu polubownego odbywanych

39 Przepis dodany ustawą z dnia 23.09.2016r. o pozasądowym rozwiązywaniu sporów konsumenckich (Dz. U. z 2016r., poz. 1823)

${ }^{40}$ Zasada równości stron stanowi naczelną zasadę procesową będąc również przewodnią w arbitrażu: Por. E. Wengerek, Zasada równości stron w procesie cywilnym, "Państwo i Prawo" 1955, z. 11, s. 788 i n. A. Jakubecki, Naczelne zasady postępowania cywilnego w świetle nowelizacji kodeksu postępowania cywilneg, Czterdziestolecie kodeksu postępowania cywilnego. Zjazd katedr postępowania cywilnego w Zakopanem (7-9.10.2005r.), Kraków 2006, s. 351 i n.; K. Korzan, Arbitraż i postępowanie arbitrażowe, Warszawa 1980, s. 192- 193; A. Góra - Błaszczykowska, Zasada równości stron w procesie cywilnym, Warszawa 2008, s. 51 i n.; J. Bodio, W. Graliński, Znaczenie zasady równouprawnienia stron w procesie cywilnym, "Studia Iuridica Lublinensia" 2016, t.. XXV, 1, s. 251 - 268; T. Strumiłło, Zasady postępowania arbitrażowego, "Kwartalnik ADR” 2009, nr 3, s. 65-68. 
w celu przeprowadzenia dowodów (art. $1189 \$ 2$ k.p.c.); uwzględnia konieczność doręczania stronie wszelkich pism składanych sądowi polubownemu przez drugą stronę jak również doręczania obu stronom opinii biegłych oraz innych dowodów na piśmie, które sąd polubowny może wziąć pod uwagę przy rozstrzyganiu sporu (art. $1189 \$ 3$ k.p.c.); nie traktuje braku odpowiedzi na pozew za przyznanie faktów przytoczonych w pozwie (art. $1190 \$ 2$ k.p.c.); oraz gwarantuje arbitrom możliwość ewentualnego poprawienia błędu (art. 1193 k.p.c.). W braku uzgodnienia przez strony kwestii zasad i sposobu postępowania przed sądem polubownym, prawo wskazania procedury arbitrażowej zyskuje sąd polubowny, który może prowadzić postępowanie w taki sposób, jaki uzna za właściwy (art. $1184 \$ 2$ k.p.c.). Jak podkreśla się w literaturze, przepisy dające stronom (sądowi arbitrażowemu) możliwość kształtowania zasad i sposobu postępowania polubownego ustanawiają bardzo liberalne ramy, w których mieści się wielka różnorodność potrzeb i okoliczności konkretnej sprawy. Jednakże w przypadku sporów wynikających z umów, których stroną jest konsument, rozstrzyganie sporu według ogólnych zasad prawa lub zasad słuszności nie może prowadzić do pozbawienia konsumenta ochrony przyznanej mu bezwzględnie wiążącymi przepisami prawa właściwego dla danego stosunku.

Rozstrzygając merytorycznie spór między stronami sąd arbitrażowy wydaje wyrok. Zgodnie z art. 1194 k.p.c., sąd polubowny rozstrzyga spór według prawa właściwego dla danego stosunku, a gdy strony go do tego wyraźnie upoważniły według ogólnych zasad prawa lub zasad słuszności. W każdym jednak przypadku sąd polubowny bierze pod uwagę postanowienia umowy oraz ustalone zwyczaje mające zastosowanie do danego stosunku prawnego. Natomiast w arbitrażu międzynarodowym tylko wyrok arbitrażowy korzysta z możliwości uznania i wykonania za granicą, głównie wg przepisów Konwencji nowojorskiej, dlatego też ustawodawca polski przewidział wzorem art. 30 ustawy modelowej możliwość nadania ugodzie formy wyroku (art. $1197 \$ 2$ k.p.c.), które ma głównie znaczenie praktyczne. ${ }^{41}$ Dla uzyskania przez ugodę formy wyroku przepisy wymagają spełnienia kilku warunków kumulatywnie. Przede wszystkim strony muszą wystąpić ze zgodnym wnioskiem o nadanie ugodzie formy wyroku. Ponadto wyrok taki musi spełniać wymagania zastrzeżone dla wyroku arbitrażowego określone w artykule 1197 k.p.c. i posiadać stwierdzenie, że jest wyrokiem sądu polubownego.

Wyrok sądu polubownego może zostać uchylony przez sąd wyłącznie w postępowaniu wszczętym na skutek wniesienia skargi o jego uchylenie. Należy jednak podkreślić, że zasada ta dotyczy wyłącznie wyroków ostatecznych. Powyższe zastrzeżenie jest konieczne, ponieważ w aktualnym stanie prawnym strony mogą ukształtować postępowanie przed sądem polubownym tak, aby obejmowało

${ }^{41}$ R. Morek, Wyrok sadu polubownego wydany na podstawie ugody stron. Zarys problematyki, Wokół problematyki orzeczeń, red. Ł. Błaszczak, Toruń 2007, s. 145 i n. 
ono więcej niż jedną instancję. Aktualna regulacja zagadnień związanych ze skargą o uchylenie wyroku sądu polubownego ujęta została w sposób dokładny i szczegółowy, co znajduje wyraz m.in. w bardziej precyzyjnym określeniu przypadków, w których strona może w drodze skargi żądać uchylenia wyroku sądu polubownego (art. 1206 k.p.c.); wprowadzenia ponownego postępowania przed sądem polubownym, które umożliwia sądowi polubownemu, którego wyrok został zaskarżony skargą o uchylenie, ponowne podjęcie postępowania w celu usunięcia przyczyn do uchylenia tego wyroku (art. 1209 k.p.c.); wydłużenie terminu do wniesienia skargi z jednego do trzech miesięcy (1208 k.p.c.); jednoznaczne potwierdzenie przyjętego $\mathrm{w}$ doktrynie i orzecznictwie poglądu, że uchylenie wyroku sądu polubownego nie powoduje wygaśnięcia zapisu na sąd polubowny, chyba że strony postanowiły inaczej.

Poza tym wyrok sądu polubownego lub ugoda przed nim zawarta mają moc prawną na równi $z$ wyrokiem sądu lub ugodą zawartą przed sądem państwowym. Aby osiągnąć wspomnianą równoważność, nadal konieczne jest przeprowadzenie specjalnego, dodatkowego postępowania. Jednakże, utrzymując wprowadzone w 2005 r. zmiany, aktualna regulacja postępowania polubownego różnicuje to postępowanie w zależności od tego, czy odnosi się ono do wyroku lub ugody nadającej się do wykonania w drodze egzekucji, czy też nie. W pierwszym przypadku, konieczne jest stwierdzenie wykonalności, które następuje w toku postępowania o nadanie klauzuli wykonalności, co znacznie upraszcza i przyspiesza postępowanie w porównaniu do stanu sprzed 2005 r., kiedy nadanie klauzuli wykonalności możliwe było dopiero po uprawomocnieniu się postanowienia stwierdzającego wykonalność. W drugim przypadku, odbywa się to natomiast w drodze uznania, o czym sąd orzeka postanowieniem wydanym na posiedzeniu niejawnym.

Wydaje się, że w oparciu o obowiązujące normy prawne większość z warunków przewidzianych dla efektywnej ochrony sądowe jest możliwa do spełnienia przez polskie sądy polubowne. Oczywiście to od woli stron, a w odniesieniu do stałych sądów arbitrażowych od ich regulaminów zależy, czy możliwości tkwiące w niektórych z tych rozwiązań (np. w zakresie zabezpieczenia roszczeń, powoływania arbitrów) zostaną wykorzystane należycie dla podniesienia sprawności i efektywności postępowania. Oczywiście sądownictwo arbitrażowe odgrywa rolę uzupełniającą, w zakresie, $w$ którym państwowy wymiar sprawiedliwości nie jest w stanie zająć się sprawą w satysfakcjonujący dla stron sposób. Odnosząc się zaś do materii samego postępowania, istotne jest zachowanie proporcji pomiędzy szybkością udzielenia ochrony prawnej, a jej skutecznością oraz wnikliwą analizą stanu faktycznego będącego podstawą rozstrzygnięcia.

Innym istotnym czynnikiem wpływającym na efektywność ochrony prawnej jest czas i koszty. Zatem szybkość arbitrażu to nie krótki czas pomiędzy wszczęciem sprawy a wyrokiem, ale przede wszystkim krótki czas trwania konfliktu. Możliwość jego zakończenia, tak by strony mogły dalej współpracować, a nie 
pozostawać w konflikcie i generować kolejne spory. Z kolei na niższe koszty postępowania arbitrażowego, może składać się także ograniczenie ogólnych kosztów i strat wynikających z powstałego konfliktu przez rozwiązanie go w sposób zapewniający ochronę gospodarczego celu stosunku, na którego podstawie toczy się spór ${ }^{42}$.

\section{Uwagi końcowe}

W konsekwencji w omawianej materii jest niezwykle trudno sformułować jednoznaczne wnioski, o tym bowiem, czy postępowanie polubowne będzie efektywne, decydowało tak w prawie rzymskim, jak i współcześnie wiele indywidualnych czynników, jak np. skład sądu polubownego oraz charakter konkretnej sprawy ${ }^{43}$.

Ważnym elementem było i jest przygotowanie sądu polubownego do rozpoznawania spraw o charakterze cywilnym. $Z$ jednej strony ważne jest sporządzenie i stosowanie jak najlepszych procedur (zapewniające szybkość i rzetelność postępowania) rozpoznawania tych spraw w toku postępowania arbitrażowego. Braki w tym względzie, mimo najwyższego stopnia profesjonalizmu zawodowego arbitrów, nie pozwolą na efektywną ochronę prawną strony, która się o nią ubiega przed sądem polubownym. $Z$ drugiej strony istotne jest właściwe podejście składu orzekającego do badanej sprawy, dążenie do jej ugodowego załatwienia, przy czym działanie z należytą starannością.

Na zakończenie można stwierdzić, że idea rzymskiego compromissum znajduje swoja kontynuację we nowożytnym zapisie na sąd polubowny. Arbitraż stanowi, zwłaszcza współcześnie, korzystną alternatywę dla sądownictwa powszechnego. Dotyczy to zarówno jurysdykcji krajowej jak i międzynarodowej. Wśród zalet arbitrażu już od czasów rzymskich wymienia się szybkość postępowania oraz niższe koszty. To strony decydują kto będzie orzekać lub w jaki sposób zostaną wybrani arbitrzy oraz na podstawie jakiej procedury toczyć się będzie postępowanie. To wszystko pozwala na takie ukształtowanie polskiego sądownictwa polubownego, które w ramach ADR, będzie stanowiło system sprawny i efektywny, udzielający skutecznej ochrony prawnej w tych przypadkach, gdy państwowy wymiar sprawiedliwości zawodzi albo po prostu jest zbędny.

${ }^{42}$ T. Wardyński, Kilka uwag o istocie arbitrażu, Księga pamiątkowa 60-lecia Sądu Arbitrażowego przy Krajowej Izbie Gospodarczej w Warszawie, red. J. Okolski, Warszawa 2010, s. 47

43 A. Kąkolecki, Praktyki arbitrażu, Księga pamiątkowa 60-lecia Sądu Arbitrażowego przy Krajowej Izbie Gospodarczej w Warszawie, red. J. Okolski, Warszawa 2010, s. 47. 


\section{Wykaz bibliograficzny:}

\section{Literatura:}

Korzan K, Arbitraż i postępowanie arbitrażowe, Warszawa 1980,

Bełdowski J., Sześciło S., Stan wymiaru sprawiedliwości w Polsce w świetle międzynarodowych badań porównawczych, http://www.monitorprawniczy.pl/index.php?mod=m_artykuly\&ci$\mathrm{d}=53 \& \mathrm{id}=2613,12.12 .2010$

Błaszczak Ł., Ludwik M., Sądownictwo polubowne (arbitraż), Warszawa 2007,

Broniewicz W., Postępowanie cywilne w zarysie, Warszawa 2008,

Budniak - Rogala A., Charakter prawny zapisu na sąd polubowny w postępowaniu cywilnym, Wrocław 2015,

Dalka S., Sądownictwo polubowne w PRL, Warszawa 1987,

Efektywność a sprawiedliwość, red. J. Wilkin, Warszawa 1997,

Ereciński T., K. Weitz, Efektywność ochrony prawnej udzielanej przez sądy w Polsce, „Przegląd Sądowy" 2005, nr 10,

Ereciński T., Weitz K., Sąd arbitrażowy, Warszawa 2008,

Flaga - Gieruszyńska K., Problem sprawności i efektywności postępowania arbitrażowego, „Kwartalnik ADR”, 2011, nr 4(16),

Góra - Błaszczykowska A., Zasada równości stron w procesie cywilnym, Warszawa 2008, s. 51 i n.; J. Bodio, W. Graliński, Znaczenie zasady równouprawnienia stron w procesie cywilnym, „Studia luridica Lublinensia" 2016, t.. XXV, 1,

Heumann H., Seckel E., Handlexicion zu den Quellen des römischen Rechts, Graz 1958,

Jakubecki A., Naczelne zasady postępowania cywilnego w świetle nowelizacji kodeksu postępowania cywilnego, Czterdziestolecie kodeksu postępowania cywilnego. Zjazd katedr postępowania cywilnego w Zakopanem (7-9.10.2005r.), Kraków 2006,

Kąkolecki A., Praktyki arbitrażu, Księga pamiątkowa 60-lecia Sądu Arbitrażowego przy Krajowej lzbie Gospodarczej w Warszawie, red. J. Okolski, Warszawa 2010,

Kierczyński Z., Czy przedsiębiorcy powinni korzystać z sq̨downictwa polubownego?, Mediacja iarbitraż jako sposoby polubownego rozstrzygania sporów, red. D. Czura-Kalinowska, Poznań 2009,

Morek R., Mediacja i arbitraż. Art. 1831 - 183 15, 1154 - 1217 KPC. Komentarz, Warszawa 2006 ,

Morek R., Wyrok sądu polubownego wydany na podstawie ugody stron. Zarys problematyki, Wokół problematyki orzeczeń, red. Ł. Błaszczak, Toruń 2007,

Mól A., Pojęcie i znaczenie alternatywnych metod rozstrzygania sporów (ADR), "Przegląd Prawa Handlowego" 2001, nr 12,

Nevai L., Efektywność a demokratyzm socjalistycznego procesu cywilnego, „Państwo i Prawo” 1973, nr 7, Nowy słownik języka polskiego, red. E. Sobol, Warszawa 2003,

Rajski J., Nowe wyzwania wobec sądów arbitrażowych, "Przegląd Prawa Handlowego" 2001, nr 1,

Rajski J., Regulamin ADR Międzynarodowej Izby Handlowej z 2001 roku, “Przegląd Prawa Handlowego" 2001, nr 11,

Sawczuk M., O efektywności socjalistycznego postępowania cywilnego, "Studia Cywilistyczne” 1975, t. XXV-XXVI,

Skoczylas J. J., Charakter prawny zapisu na sąd polubowny a autonomia regulacji prawnej arbitrażu (po nowelizacji z 2005 roku), Księga pamiątkowa 60-lecia Sądu Arbitrażowego przy Krajowej lzbie Gospodarczej w Warszawie, red. J. Okolski, A. Całus, M. Pazdan, S. Sołtysiński, E. Wardyński, S. Włodyka, Warszawa 2010,

Sobolewski P., Mediacja w sprawach cywilnych, „Przegląd Prawa Handlowego" 2006, nr 2,

Sondel J., Szczególne rodzaje depozytu w prawie rzymskim, Kraków 1967, 
Stelmach B., Brożek B., Dziesięć wykładów o ekonomii prawa, Kraków 2007,

Strumiłło T., Zasady postępowania arbitrażowego, "Kwartalnik ADR" 2009, nr 3,

Tomaszewski M., Skuteczność ochrony prawnej przed sądami polubownym. Doświadczenia polskie, „Przegląd Sądowy” 2006, nr 1,

Tomaszewski M., Umowa o arbitraż, System Prawa Handlowego. Arbitraż handlowy. red. S. Włodyka, A. Szumański, t. 8, Warszawa 2010,

Wach A., Alternatywne formy rozwiqzywania sporów sportowych, Warszawa 2005,

Wardyński T., Kilka uwag o istocie arbitrażu, Księga pamiątkowa 60-lecia Sądu Arbitrażowego przy Krajowej Izbie Gospodarczej w Warszawie, red. J. Okolski, Warszawa 2010,

Weitz K., Sądownictwo polubowne a sq̨downictwo państwowe, „Przegląd Sądowy” 2007, nr 3,

Wengerek E., Zasada równości stron w procesie cywilnym, „Państwo i Prawo” 1955, z. 11,

Wojciechowski B., Rozpoznanie sprawy w rozsądnym terminie. Uwagi na tle tworzenia europejskiego kodeksu postępowania cywilnego i orzecznictwa Europejskiego Trybunału Praw Człowieka, Teoretycznoprawne problemy integracji europejskiej, red. L. Leszczyński, Lublin 2004,

Zedler F., Zapis na sąd polubowny, Umowy w obrocie gospodarczym, red. A. Koch, J. Napierała, Warszawa 2006,

Żołnierczuk M., Rzymskie sądownictwo polubowne (okres przedklasyczny i klasyczny), Lublin 1978,

\section{Orzecznictwo:}

Orzeczenie 222/84 Marguerite Johnston u. Chief Constable of the Royal Ulster Constabulary [1986] ECR 1651, pkt 14

Orzeczenie 222/84 Marguerite Johnston u. Chief Constable of the Royal Ulster Constabulary [1986] ECR 1651, pkt 14

\section{Akty prawne:}

Ustawa z dnia 17.11.1964r., - Kodeks postępowania cywilnego (t.j. Dz. U. z 2016, poz. 1822 ze zm.). Ustawa z dnia 23.09.2016r. o pozasądowym rozwiązywaniu sporów konsumenckich (Dz. U. z 2016r., poz. 1823)

\section{Streszczenie}

Zasada efektywności, chociaż nie została wyraźnie wyartykułowana w traktatach, pełni istotną funkcję w systemie unijnej ochrony prawnej. Oczywiście problem efektywności prawa może być rozpatrywany już na etapie jego stanowienia, ale przedmiotem niniejszego opracowania są elementy związane $\mathrm{z}$ efektywną ochroną praw podmiotowych.

Sprawy z zakresu prawa prywatnego mogą być załatwiane nie tylko przez państwowe organy sądowe, lecz także przez powołane do tego wolą stron sądy polubowne. Jest to możliwe dzięki fundamentalnej dla prawa prywatnego zasadzie autonomii woli, która na gruncie postępowania cywilnego wraża się m.in. poprzez umożliwienie stronom dokonania wyboru, czy zwrócą się o udzielenie ochrony do sądu państwowego, czy skorzystają z innej drogi dochodzenia roszczenia. Sąd arbitrażowy powinien pełnić zatem nie tylko funkcję organu rozstrzygającego spory w trybie orzeczniczym, ale co istotniejsze powinien rozwiązywać te spory przy udziale stron tak, aby możliwe było ich pojednanie lub co najmniej zapobieganie dalszej antagonizacji. 
Stąd też tak istotne jest zadbanie o sprawność i efektywność postępowań toczących się przed sądem polubownym, i spojrzenie na te kwestie w szerszym aspekcie postępowania cywilnego. Wynika to przede wszystkim z faktu, że chociaż sądownictwo polubowne nie jest częścią składową sądownictwa państwowego, to jednak działając zamiast sądów państwowych i udzielając ochrony prawnej, jako takie realizują zadania, które należą do państwa, zatem państwo sankcjonuje działalność sądów polubownych. Tym samym wiele problemów odnoszących się do przebiegu postępowania przed sądem powszechnym można odnaleźć również w toku postępowania arbitrażowego, choć dzięki mniejszemu formalizmowi to ostatnie z pewnością dysponuje większym zakresem środków, pozwalających na uniknięcie niesprawności i nieefektywności prowadzonych czynności.

Oczywiści trudno jest jednoznaczne stwierdzić, czy postępowanie polubowne jest efektywne, decyduje o tym bowiem wiele indywidualnych czynników, jak np. skład sądu polubownego oraz charakter konkretnej sprawy.

Ważnym elementem jest przygotowanie sądu polubownego do rozpoznawania spraw o charakterze cywilnym. Z jednej strony ważne jest sporządzenie i stosowanie jak najlepszych procedur (zapewniające szybkość i rzetelność postępowania) rozpoznawania tych spraw w toku postępowania arbitrażowego. Braki w tym względzie, mimo najwyższego stopnia profesjonalizmu zawodowego arbitrów, nie pozwolą na efektywną ochronę prawną strony, która się o nią ubiega przed sądem polubownym. $\mathrm{Z}$ drugiej strony istotne jest właściwe podejście składu orzekającego do badanej sprawy, dążenie do jej ugodowego załatwienia, przy czym działanie z należytą starannością.

Tak było już w prawie rzymskim, ponieważ rzymska myśl prawna twórczo zaadaptowana do potrzeb kolejnych pokoleń, znajduje swoje zastosowania również wobec wyzwań współczesnego procesu cywilnego. W tym także w odniesieniu do kwestii związanych z potrzebą zapewnienia realizacji prawa dostępu do sądu i prawa do efektywnego procesu cywilnego.

Słowa kluczowe: alternatywne sposoby rozwiązywania sporów, arbitraż, zapis na sąd polubowny, compromissum, efektywna ochrona prawna.

\section{Relationship between alternative dispute resolution methods and effectiveness of legal protection}

\section{Summary}

Even though it has not been explicitly articulated in the treaties, the principle of effectiveness plays an important role in the EU system of legal protection. The problem of their effectiveness may, obviously, be examined at the stage of creating the laws, yet this study focuses on selected aspects of effective protection of subjective rights.

Private law cases may be handled not only by national judicial bodies, but also by courts of arbitration appointed for the purpose by the will of the parties involved. This is enabled by the principle of party autonomy, fundamental under private law, which in proceedings under civil law is expressed e.g. by the parties' freedom to decide whether they will turn for protection to national court of law or will pursue their claims otherwise. Hence, in addition to its function as a body resolving disputes by means of adjudication, court of arbitration should settle the matters with the interested parties so that it becomes possible to reconcile differences between them, or at least to prevent further estrangement.

Given the above, it is particularly important to ensure efficiency and effectiveness of proceedings held before courts of conciliation and to look at these issues in a broader context of civil proceedings. This mainly results from the fact that although arbitration system is not part of national jurisdiction, by acting in place of national courts of justice and providing legal protection, courts of arbitration perform tasks designated to the state, therefore their operation is sanctioned by the state. Conse- 
quently, numerous problems related to the course of proceeding before common courts of law can also be identified in arbitration procedures, even though the latter, having more flexibility, may apply a wider range of means to avoid the inefficiency and lack of effectiveness in their operations.

It is obviously difficult to explicitly decide whether or not arbitration proceeding is effective as this depends on a number of factors, such as the composition of the arbitration court and nature of the specific case. Another matter of importance is the competence of the arbitration body in handling claims in civil proceedings. On the one hand it is important to define and apply optimum procedures in examining such cases under arbitration proceeding (to ensure rapid and fair settlement). Any related deficiencies, despite professional expertise of the arbiters, will be an impediment to effective legal protection for the party bringing their claim to arbitration court. On the other hand, it is crucial that the adjudicating panel applies adequate approach to the relevant matter, aiming at its amicable resolution and acting with due diligence.

This was already the case in Roman law, because Roman legal concepts creatively adapted to the needs of the successive generations, are also applicable to challenges of the modern civil proceeding. This also relates to the need to ensure access to jurisdiction and to enforce the right of effective civil law procedure.

Keywords: alternative dispute resolution methods, arbitration, request for arbitration, compromissum, effective legal protection. 